\title{
Thyroid Hormone Receptor-Associated Protein 3
}

National Cancer Institute

\section{Source}

National Cancer Institute. Thyroid Hormone Receptor-Associated Protein 3. NCI

Thesaurus. Code C97842.

Thyroid hormone receptor-associated protein 3 (955 aa, $\sim 109 \mathrm{kDa}$ ) is encoded by the human THRAP3 gene. This protein is involved in transcriptional activation. 